\title{
PENERAPAN MODEL PKTB DAN PKDLB DALAM MENINGKATKAN HASIL BELAJAR PASSING BAWAH BOLA VOLI
}

\author{
Indra Kasih, Irvan Darmawan \\ Fakultas Ilmu Keolahragaan, Universitas Negeri Medan, Medan, Indonesia \\ Correspondence: Fakultas Ilmu Keolahragaan, Universitas Negeri Medan, Medan, \\ Indonesia. E-mail:
}

\begin{abstract}
Abstrak
Penelitian ini bertujuan untuk mengetahui peningkatan hasil belajar passing bawah bola voli melalui penerapan model PKTB dan PKDLB. Penelitian ini merupakan Penelitian Tindakan Kelas (PTK). Penelitian dilakukan dalam dua siklus. Subjek penelitian adalah kelas XI IPA ${ }^{11}$ sebanyak 30 siswa yang terdiri dari 11 putra dan 19 putri. Penelitian dilaksanakan di SMA Negeri 2 Medan pada tanggal 23 Juli s/d 30 Juli 2016. Teknik pengumpulan data menggunakan lembar observasi dan portofolio penilaian tes. Hasil penelitian siklus I setelah dilakukan post test siklus I dari 30 siswa terdapat 18 siswa (60\%) tuntas dan 12 orang (40\%) tidak tuntas dengan nilai rata-rata 71,08 (tidak tuntas). Hasil penelitian siklus II setelah dilakukan post test siklus II dari 30 siswa terdapat 26 siswa (86,66\%) tuntas dan 4 siswa (13,33\%) tidak tuntas dengan nilai rata-rata 78,53 (tuntas). Kenaikan nilai rata-rata antara siklus I dan siklus II adalah sebesar 7,47. Berdasarkan hasil analisis data tersebut dapat disimpulkan bahwa dengan menggunakan model PKTB dan PKDLB dapat meningkatkan hasil belajar passing bawah bola voli pada siswa kelas XI IPA ${ }^{11}$ SMA Negeri 2 Medan Tahun Ajaran 2016/2017.
\end{abstract}

Kata Kunci: Model PKTB dan PKDLB

\section{Pendahuluan}

Pendidikan jasmani merupakan suatu bentuk pendidikan yang tidak terlepas dari pendidikan secara keseluruhan. Pendidikan jasmani sebagai komponen pendidikan secara keseluruhan telah disadari oleh banyak kalangan. Namun, dalam pelaksanaannya pengajaran pendidikan jasmani berjalan belum efektif seperti yang diharapkan. Pendidikan jasmani, olahraga, dan kesehatan merupakan media untuk mendorong pertumbuhan fisik, perkembangan psikis, keterampilan motorik, pengetahuan dan penalaran penghayatan nilainilai (Sikap-mental-emosional-sportivitas-spiritual-sosial), serta pembiasaan pola hidup sehat yang bermuara untuk merangsang pertumbuhan dan perkembangan kualitas fisik dan psikis yang seimbang.

Berdasarkan hasil observasi yang telah dilakukan peneliti di SMA Negeri 2 Medan Jl. Karang Sari, no 435, Kecamatan Polonia, Medan, Sumatera Utara dengan melakukan wawancara kepada salah satu guru mata pelajaran pendidikan jasmani, diperoleh bahwa Kriteria Ketuntasan Minimal (KKM) di sekolah tersebut adalah 75. Gaya mengajar yang digunakan guru pendidikan jasmani disekolah tersebut adalah dengan memberikan demonstrasi atau contoh gerak passing bawah, kemudian siswa berlatih melakukan gerakan seperti yang didemonstrasikan guru. 
Diketahui bahwa hasil belajar siswa dalam pelajaran bola voli dengan materi passing bawah bola voli, masih banyak siswa yang memperoleh nilai rendah. Nilai rata-rata hasil belajar siswa secara keseluruhan adalah 65,23. Dari 30 siswa kelas XI IPA ${ }^{11}$ ternyata 18 siswa (60\%) memiliki nilai dibawah KKM dan 12 siswa (40\%) memiliki nilai diatas KKM. Hal ini merupakan salah satu permasalahan yang harus dicari solusinya. realitanya guru bidang studi pendidikan jasmani di sekolah tersebut masih kurang kreatif merangsang keaktifan siswa dalam praktek penjas karena berbagai macam keterbatasan sarana dan prasarana bola voli. Dimana, lapangan bola voli ada 1 dan jumlah bola voli yang tersedia hanya ada 2 buah, sehingga kurang mendukung proses pembelajaran. Guru penjas dalam melaksanakan pembelajaran passing bawah masih kurang menggunakan model pembelajaran.

Untuk mengatasi masalah tersebut, diperlukan metode ataupun model pembelajaran yang dapat mendukung guru dalam meningkatkan kemampuan siswa melakukan passing bawah dengan baik dan akurat. Salah satu model pembelajaran yang dapat diterapkan adalah Model Passing Kursi Tanpa Bola (PKTB) dan Passing Kursi Dengan Lemparan Bola (PKDLB). Model $P K T B$ Dan $P K D L B$ merupakan salah satu model hal yang baru bagi siswa, diharapkan dengan model $P K T B$ dan $P K D L B$ siswa tidak sulit untuk melakukan gerakan passing bawah bola voli.

\section{Hakikat Pendidikan Jasmani}

Pendidikan jasmani pada dasarnya merupakan suatu proses pendidikan melalui aktifitas yang didesain untuk meningkatkan kebugaran jasmani, mengembangkan keterampilan motorik, pengetahuan dan perilaku hidup sehat dan aktif, sikap sportif, dan kecerdasan emosi. Menurut Sharman dalam Nadisah (1992: 15) mengemukakan "bahwa pendidikan jasmani adalah bagian dari pendidikan (secara umum) yang berlangsung melalui aktivitas yang melibatkan mekanisme gerak tubuh manusia dan menghasilkan pola-pola perilaku pada individu yang bersangkutan".

Menurut Dini Rosdiani (dalam Kasih 2016 : 1) menyatakan bahwa pendidikan jasmani adalah bagian integral dari proses pendidikan secara total, yang bertujuan utuk mengembangkan warga negara menjadi segar fisik, mental, emosional, dan sosial melalui aktifitas fisik. jasmani yang terpilih dengan maksud untuk merealisasi hasil-hasil pendidikan tersebut" (1992: 16).

\section{Hakikat Olahraga}

Hakikat Pendidikan Olahraga Kalaupun olahraga bukan merupakan perpanjangan pendidikan jasmani, namun demikian kemampuan gerak dasar yang menyeluruh (general motor ability) akan menjadi landasan kuat bagi anak dalam penguasaan keterampilan olahraganya. Pendidikan jasmani akan mengarahkan proses belajar itu pada pengembangan keterampilan gerak insani sebagai bekal keterampilan hidup (life skill) sedangkan pendidikan olahraga akan mengarah kepada penguasaan suatu keterampilan cabang olahraga. Kalaupun substansi proses dari pendidikan jasmani itu berlainan namun demikian keduanya sama-sama bertendensi perilaku gerak, (Anin Rukmana, 2008)

\section{Hakikat Belajar}

Belajar merupakan proses aktif yang mengarah pada satu tujuan. Seseorang dikatakan belajar apabila terjadi perubahan tingkah laku seperti dari yang tidak tahu menjadi tahu. Kegiatan belajar dapat berlangsung melalui proses pengamatan, pendengaran, membaca, dan meniru. Menurut Biggs (dalam Kasih, 2016 : 3), menyatakan bahwa belajar 
dicirikan oleh suatu perubahan yang bertahan lama dalam kehidupan individu dan tidak dilahirkan atau didahului oleh warisan keturunan. Menurut Winkel (dalam Riyanto, 2009), belajar adalah suatu aktivitas mental/psikis yang berlangsung dalam interaksi aktif dengan lingkungan,yang menghasilkan perubahan - perubahan dalam pengetahuan, pemahaman, keterampilan, dan nilai - sikap. Perubahan itu bersifat secara relative konstan dan berbekas.

\section{Hakikat Hasil Belajar}

Menurut Hamalik hasil belajar adalah bila seseorang telah belajar akan terjadi perubahan tingkah laku pada orang tersebut, misalnya dari tidak tahu menjadi tahu, dan dari tidak mengerti menjadi mengerti. Hasil belajar adalah kemampuan-kemampuan yang dimiliki siswa setelah ia menerima pengalaman belajarnya. Hasil belajar digunakan oleh guru untuk dijadikan ukuran atau kriteria dalam mencapai suatu tujuan pendidikan. Hal ini dapat tercapai apabila siswa sudah memahami belajar dengan dïringi oleh perubahan tingkah laku yang lebih baik lagi.

\section{Hakikat Model Pembelajaran}

Secara umum istilah model diartikan sebagai kerangka konseptual yang digunakan sebagai gambaran suatu lingkungan pembelajaran yang juga meliputi perilaku kita sebagai guru saat model tersebut diterapkan (Joyce, $2009: 30$ ).

Pernyataan yang sama juga disampaikan oleh Joyce dan Weil (dalam Sagala 2009 : 176 ) yang menyatakan bahwa :

"Model pembelajaran adalah suatu deskripsi dari lingkungan belajar yang menggambarkan perencanaan kurikulum, kursus-kursus, desain unit-unit pelajaran dan pembelajaran, perlengkapan belajar, buku-buku pelajaran, buku-buku kerja, program multimedia dan bantuan belajar melalui program komputer".

\section{Hakikat Model Pembelajaran}

Permainan bola voli adalah suatu cabang olahraga berbentuk mem-voli bola diudara hilir mudik diatas jaring/net, dengan maksud dapat menjatuhkan bola didalam petak lapangan lawan untuk mencari kemenangan dalam bermain. Mem-voli dan memantulkan bola ke udara harus mempergunakan bagian tubuh pinggang keatas dengan pantulan yang sempurna (Imam Soejoedi, 1979 : 17). Tujuan permainan bola voli adalah berusaha menjatuhkan bola ke lapangan lawan dengan menyebrangkan bola di atas net atau jaring.

\section{Hakikat Passing Bawah Bola Voli}

Menurut Kasih (2016 : 71) "Passing adalah mengoper bola kepada teman sendiri dalam satu regu dengan suatu tekhnik tertentu, sebagai langkah awal untuk menyusun pola serangan kepada regu lawan. Kasih (2016:71) mengemukakan bahwa 'teknik gerakan passing bawah dibagi kepada tiga bagian yakni : 1. Sikap Permulaan, 2. Gerak Pelaksanaan, 3. Gerak Lanjutan “.

\section{Hakikat Model PKTB Dan PKDLB}

Dikutip Kasih (2016 : 76) PKTB adalah singkatan dari passing kursi tanpa bola, bentuk $P K T B$ merupakan bentuk model pembelajaran dan latihan passing bawah bola voli.

a. Pengertian pembelajaran dan latihan model $P K T B$ menurut Kasih (2016 : 76) adalah pembelajaran dan latihan yang dilakukan dengan media bantu kursi dalam upaya memberikan pengetahuan dasar tentang posisi ideal kaki, badan dan tangan dalam 
melakukan passing. Model ini juga akan mengaplikasi pengetahuan kognitif, motorik, sehingga akan memberikan pemahaman terhadap kebutuhan posisi tubuh dalam melakukan pass bawah.

b. Tujuan pembelajaran dan latihan model PKTB menurut Kasih (2016 : 76) adalah sebagai berikut:

1. Memberikan pengetahuan kognitif kepada peserta didik tentang tujuan alat bantu kursi dalam pelaksanaan passing bawah.

2. Memberikan pengetahuan kognitif dan gerak (motorik) kepada peserta didik tentang posisi badan, kaki, tangan ideal serta dapat melakukan passing bawah dengan alat bantu kursi.

3. Memberikan pengetahuan kognitif kepada peserta didik tentang posisi badan, kaki, tangan ideal setelah melakukan passing bawah dengan alat bantu kursi.

c. Langkah-langkah pelaksanaan pembelajaran dan latihan model PKTB menurut Kasih $(2016: 76)$ adalah sebagai berikut :

1. Siapkan bangku dengan ketinggian $60 \mathrm{~cm}$ (sesuaikan dengan kondisi siswa).

2. Peserta didik akan duduk dibangku dengan membuka kedua kaki sejajar dengan

bahu.

3. Letakan kedua tangan disamping kiri dan kanan dengan posisi lurus.

4. Bawa kedua tangan kedepan sejajar dengan pusat.

5. Pautkan kedua tangan (tangan kanan dibawah dan kiri diatas) kemudian genggam sambil mempertemukan kedua ibu jari.

6. Bawa badan berdiri, langkahkan kaki selebar $30 \mathrm{~cm}$ sambil mengayunkan tangan lurus kedepan.

7. Setelah selesai lepaskan kedua tangan sambil bawa badan kembali duduk diatas bangku.

8. Lakukan gerakan ini sambil anda mendapatkan posisi badan yang ideal saat melakukan gerakan passing bawah.

9. Gerakan ini juga bisa dilakukan siswa dengan maju satu sampai beberapa langkah kedepan.

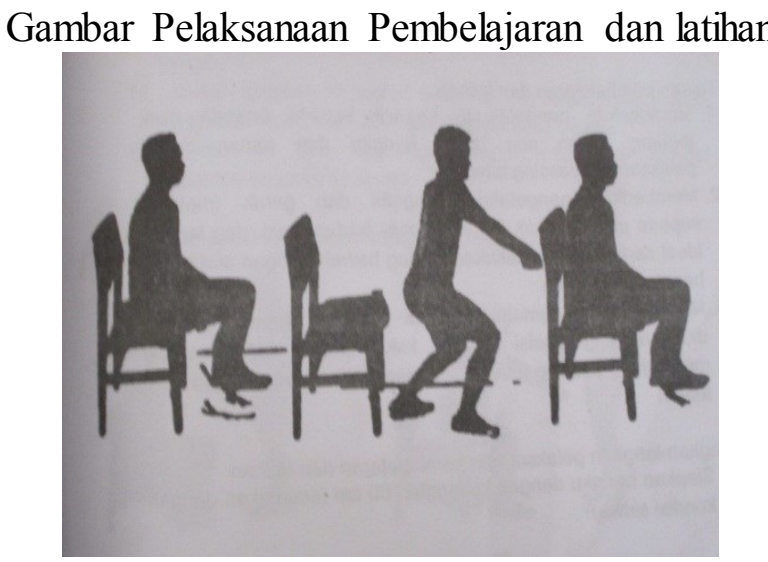

Gambar 1. Penerapan Model PKTB

(Indra Kasih, 2016 : 77) 
d. Evaluasi pembelajaran dan latihan $P K T B$ menurut Kasih (2016 : 76) adalah sebagai berikut:

1. Hindari pembengkokan tangan saat melakukan gerakan passing.

2. Hindari memegang tangan setelah melakukan gerakan passing saat kembali ke bangku.

\section{Model PKDLB (Passing Kursi Dengan Lemparan Bola)}

a. Pengertian pembelajaran dan latihan model PKDLB menurut Kasih (2016 : 80) adalah pembelajaran dalam upaya memberikan pengetahuan kepada siswa dengan melakukan passing menggunakan bantuan alat bantu kursi dan bantuan teman yang berguna untuk memberikan pengalaman langsung dengan bersentuhan dengan bola serta mempermudah dalam memahami seperti apa tekhnik dalam melaksanakan passing dengan sempurna. Model ini juga akan mengaplikasi pengetahuan kognitif, motorik, sehingga akan memberikan pemahaman terhadap ketepatan dalam melakukan pass bawah dengan baik dan benar.

b. Tujuan pembelajaran dan latihan dari model $P K D L B$ menurut Kasih (2016: 80) adalah sebagai berikut:

1. Memberikan pengetahuan kognitif kepada peserta didik tentang tujuan alat bantu kursi, teman dan bola dalam pelaksanaan passing bawah.

2. Memberikan pengetahuan kognitif dan gerak (motorik) kepada siswa tentang posisi badan, kaki, dan tangan ideal serta dapat melakukan passing bawah dengan alat bantu kursi dan bantuan lemparan bola oleh teman.

3. Memberikan pengetahuan kognitif dan psikomotor kepada peserta didik tentang pelaksanaan passing dengan posisi badan, kaki, tangan ideal setelah melakukan passing bawah dengan bantuan alat bantu kursi dan bantuan teman dengan melempar bola.

c. Langkah -langkah pelaksanaan pembelajaran dan latihan model $P K D L B$ menurut Kasih (2016 : 81) adalah sebagai berikut:

1. Siapkan bangku dengan ketinggian $60 \mathrm{~cm}$ (sesuaikan dengan kondisi siswa).

2. Peserta didik akan duduk dibangku dengan membuka kedua kaki sejajar dengan bahu.

3. Peserta didik duduk di kursi dan berhadapan dengan jarak $4 \mathrm{~s} / \mathrm{d} 5$ meter.

4. Peserta didik yang akan melakukan passing duduk dengan sempurna.

5. Pandangan mengarah ke teman yang akan melemparkan bola.

6. Saat bola dilempar, lihat alur bola dan bersiap melakukan passing.

7. Letakkan kedua tangan (tangan kanan dibawah dan kiri diatas) kemudian genggam sambil mempertemukan kedua ibu jari.

8. Peserta didik diharapkan fokus untuk menerima lemparan bola dari teman guna mendapatkan posisi bola ideal (untuk mendapatkan sudut elevansi).

9. Lakukan gerakan mengayun tangan lurus kedepan atas mengenai bola dengan kekuatan disesuaikan dengan target (teman) dengan gerakan tangan tidak boleh melewati bahu.

10. setelah selesai, lepaskan kedua tangan, dan lakukan gerakan ini sambil anda mendapatkan posisi tangan dan ayunan tangan ideal saat melakukan gerakan passing bawah. 


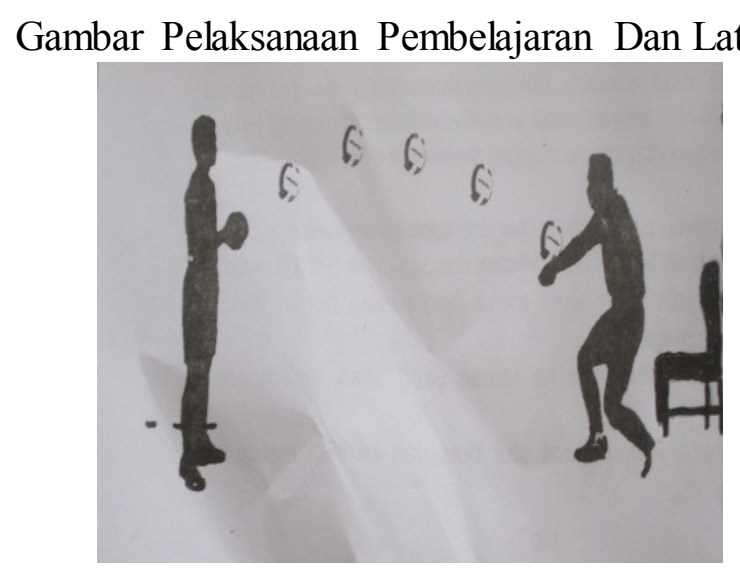

\section{Gambar 2. Penerapan Model PKDLB}

$\underline{\text { (Indra Kasih, 2016:81) }}$

d. Evaluasi pembelajaran dan latihan menurut Kasih (2016 : 80) adalah sebagai berikut :

1. Hindari melakukan passing dengan siku membengkok, sebab akan membuat alur bola tidak sempurna.

2. Jangan memegang tangan dengan terus melakukan passing.

3. Hindari kedua kaki sejajar sebab membuat keseimbangan dalam gerakan terganggu.

4. Hindari melakukan passing keatas terlalu rendah dan tinggi sebab akan membuat kendali dalam melakukan passing selanjutnya akan sulit.

\section{Metode}

Penelitian dilaksanakan dengan desain PTK (Penelitian Tindakan Kelas). Pelaksanaan tindakan direncanakan dengan satu siklus. Siklus terdiri atas perencanaan, pelaksanaan, pengamatan dan reflex. Sesuai dengan permasalahan dan tujuan yang dimaksud, untuk mendapatkan informasi tentang Penerapan model PKTB dan PKDLB dalam meningkatkan hasil belajar passing bawah bola voli pada siswa kelas XI IPA SMA Negeri 2 Medan Tahun Ajaran 2016/2017, peneliti menggunakan metode yang dianggap sesuai dengan permasalahan yang hendak diteliti yaitu menggunakan metode Penelitian Tindakan Kelas (PTK).

Prosedur penelitian ini dilakukan dalam beberapa tahap pelaksanaan tindakan sebagai berikut:

\section{Siklus I}

a. Tahap perencanaan tindakan kelas

b. Tahap pelaksanaan tindakan kelas

c. Tahap pengamatan

d. Tahap refleksi 
Instrumen Penelitian

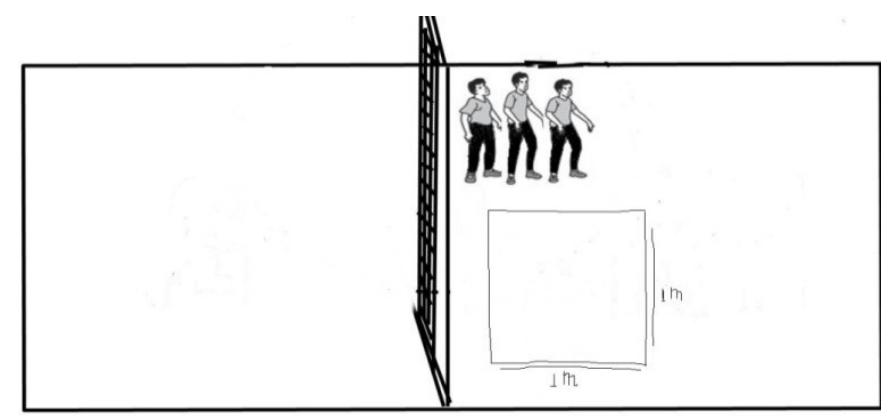

Analisis data yang dilakukan terdiri dari beberapa tahap diantaranya:

1. Reduksi data

2. Paparan data

Tabel 2. Indikator dan Deskriptor Penilaian

\begin{tabular}{|l|c|c|c|c|}
\hline \multicolumn{1}{|c|}{ Indikator } & \multicolumn{4}{c|}{ Deskriptor } \\
\hline Sikap awal & 4 & 3 & 2 & 1 \\
\hline Sikap perkenaan & 4 & 3 & 2 & 1 \\
\hline Sikap akhir & 4 & 3 & 2 & 1 \\
\hline
\end{tabular}

Dengan kriteria ketuntasan belajar

$$
K K M=\frac{\text { sikapawal }+ \text { sikapperkenaan }+ \text { sikapakhir }}{\text { JumlahDeskriptor }} X 100 \%
$$

- $75-100=$ tuntas

- $0-74=$ tidak tuntas

- Mencari ketuntasan belajar siswa secara klalis dengan rumit:

- $\mathrm{PKK}=\frac{M}{N} X 100 \%$

- Keterangan

- PPK : persentasi ketuntasan klasikal

- M : banyaknya siswa yang $K K M \geq 75$

- N : banyaknya siswa keseluruhan

- Suryosubroto (1997: 129) 
Hasil dan Pembahasan Penelitian

Deskripsi Data Hasil Belajar Passing Bawah Bola Voli

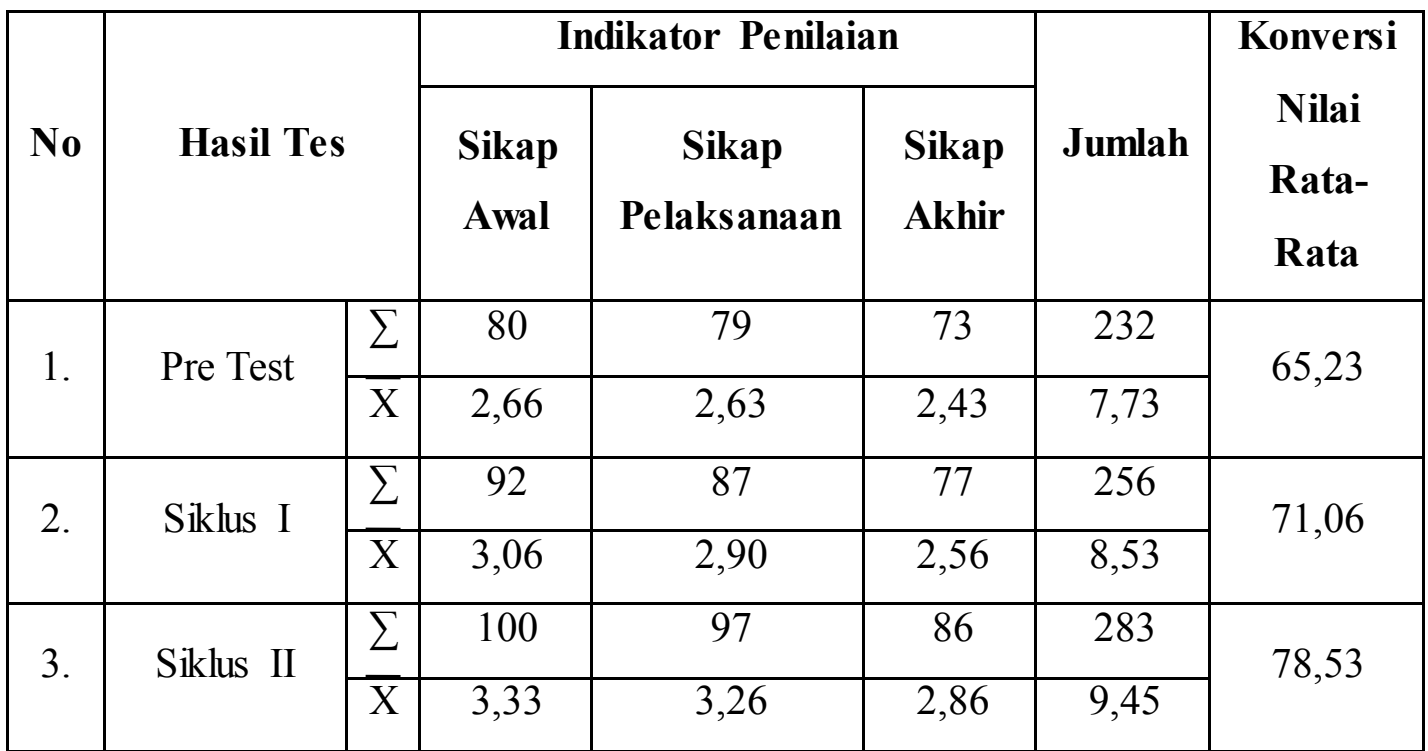

Dari tabel diatas dapat dilihat bahwa pada data awal (pre test) skor indikator sikap awal secara keseluruhan berjumlah (80) dengan rata-rata $(2,66)$, sikap pelaksanaan (79) dengan rata-rata $(2,63)$ dan sikap akhir $(73)$ dengan rata-rata $(2,43)$. Skor keseluruhan indikator berjumlah (235) dan jumlah rata-rata keseluruhan adalah $(7,83)$ dengan konversi nilai rata-rata 65,23 .

Pada siklus I skor indikator sikap awal secara keseluruhan berjumlah (92) dengan rata-rata $(3,06)$, sikap pelaksanaan $(87)$ dengan rata-rata $(2,90)$ dan sikap akhir $(77)$ dengan rata-rata (2,56). Skor keseluruhan indikator berjumlah (256) dan jumlah rata-rata keseluruhan adalah $(8,53)$ dengan konversi nilai rata-rata 71,06 . Pada siklus II skor indikator sikap awal secara keseluruhan berjumlah (100) dengan rata-rata $(3,33)$, sikap pelaksanaan (97) dengan rata-rata $(3,26)$ dan sikap akhir $(86)$ dengan rata-rata $(2,86)$. Skor keseluruhan indikator berjumlah (283) dan jumlah rata-rata keseluruhan adalah $(9,43)$ dengan konversi nilai rata-rata 86,66 .

Data Ketuntasan Hasil Belajar Passing Bawah Bola Voli ( Siklus I)

\begin{tabular}{|c|c|c|c|c|}
\hline No & Hasil Tes & Keterangan & Jumlah Siswa & Presentase \\
\hline 1. & Skor $\geq 75$ & Tuntas & 18 & $60 \%$ \\
\hline 2. & Skor $<75$ & Tidak Tuntas & 12 & $40 \%$ \\
\hline \multicolumn{2}{|c|}{ Jumlah } & 30 & $100 \%$ \\
\hline
\end{tabular}


Data Ketuntasan Hasil Belajar Passing Bawah Bola Voli ( Siklus II )

\begin{tabular}{|c|c|c|c|c|}
\hline No & Hasil Tes & Keterangan & Jumlah Siswa & Presentase \\
\hline 1 & Skor $\geq 75$ & Tuntas & 26 & $86,66 \%$ \\
\hline 2 & Skor $<75$ & Tidak Tuntas & 4 & $13,33 \%$ \\
\hline \multicolumn{2}{|c|}{ Jumlah } & 30 & $100 \%$ \\
\hline
\end{tabular}

Dengan demikian dapatlah dikatakan melalui penerapan model PKTB dan PKDLB yang di terapkan oleh guru berakhir pada siklus II dengan hasil belajar passing bawah bola voli yang tadinya rendah menjadi meningkat. Apabila nilai PKK lebih besar dari $85 \%$ maka telah tercapai ketuntasan belajar klasikal.

\section{Kesimpulan dan Saran}

Setelah dibahas dibab IV dapat ditarik kesimpulan bahwa dengan menggunakan model PKTB dan PKDLB dapat meningkatkan hasil belajar passing bawah bola voli pada siswa kelas XI IPA ${ }^{11}$ SMA Negeri 2 Medan Tahun Ajaran 2016/2017.

\section{Referensi}

Arikunto, Suharsimi, Penelitian Tindakan Kelas. Jakarta: BumiAksara, 2010.

Ahmadi, Nuril, Panduan Olahraga Bola Voli. Solo: Era Pustaka Utama, 2007.

Dimyanti dan Mudjiono, Belajar dan Pembelajaran. Jakarta: Rineka Cipta, 2003.

Istarani, 58 Model Pembelajaran Inovatif. Medan: Media Persada, 2012.

Joyce, Bruce dkk, Model of teaching. Yogyakarta: Pustaka belajar, 2009.

Kasih, Indra, Belajar Dan Berlatih Pass Bawah dan Pass Atas. Medan: Unimed Press, 2016.

Lorenzo, Tekhnik Passing Bawah dan Passing Atas Permainan Bola Voli. Bandung: Arkola, 2002.

Lutan, Rusli dan Suherman, Adang, Pengukuran dan Evaluasi Penjaskes. Jakarta: Departemen Pendidikan Nasional, 2000.

Muhajir, Pendidikan Jasmani Olahraga dan Kesehatan. Bandung: Yudistira, 2006.

Nadisah, Pengembangan Kurikulum Pendidikan Jasmani dan Kesehatan. Bandung: Departemen Pendidikan Dan Kebudayaan, 1992.

Suryosubroto, Proses Belajar Mengajar di Sekolah. Jakarta: Rineka Cipta, 1997.

Supandi, Strategi Belajar Mengajar Penjas. Jakarta: Depdikbud, 1992.

Trianto, Mendesain Model Pembelajaran Inovatif-Progresiv. Jakarta: Kencana Prenada Media Group, 2010.

Wilis, Dahar, Teori-teori Belajar. Bandung: Erlangga, 1989. 